\title{
First report of leafminer Lyriomyza spp. in Daucus carota in Brazil
}

\author{
F. L. Fernandes ${ }^{*}$, M. E. De S. Fernandes ${ }^{a}$, N. C. R. Costa ${ }^{a}$, R. C. Pereira ${ }^{b}$, \\ A. L. Dos Santos ${ }^{a}$ and R. C. Ribeiro ${ }^{c}$ \\ anstituto de Ciências Agrárias, Universidade Federal de Viçosa - UFV, Campus de Rio Paranaíba, \\ MG 230, Km 8, CEP 38810-000, Rio Paranaíba, MG, Brazil

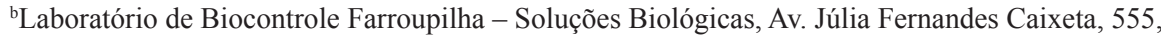 \\ CEP 38706-420, Patos de Minas, MG, Brazil
}

'Faculdade de Agronomia, Universidade Federal do Pará - UFPA, Campus Universitário do Tocantins-Cametá, Rua Padre Antônio Franco, 01, CEP 68400-000, Cametá, PA, Brazil

*e-mail: flaviofernandes@ufv.br

Received: March 10, 2016 - Accepted: May 20, 2016 - Distributed: August 31, 2017

(With 1 figure)

Diptera, Lepidoptera, and Coleoptera are the taxonomic groups of leaf miners more common of the world (Foba et al., 2015; Jahnke et al., 2008; Queiroz, 2002; Marchiori et al., 2004). The dipterous agromyzid leaf miner, Lyriomiza spp., are a more important polyphagous pest of the vegetables species of plants (Foba et al., 2015) in the Americas. The Liriomyza huidobrensis (Blanchard), L. trifolii (Burgess), and L. sativae (Blanchard) have been recorded as the most important leafminer pests in vegetable production systems in word (Guantai et al., 2015). More than $87 \%$ of the Liriomyza species attacking Pisum sativum L., Phaseolus vulgaris L., Solanum lycopersicum L., and Solanum tuberosum (Foba et al., 2015). Adults, males and females, feeding of the leaves and its immature stage (larvae) feeding of palisade parenchyma tissue (Bueno et al., 2007). In addition, the females of $L$. spp. are vector of diseases by transference during feeding or egg laying (Durairaj et al., 2010). Liriomyza have a hability of rapid dispersal and colonization of different landscapes, often in association with global trade and transportation (Weintraub, 2001). It has been reported that all plants, but nothing is known about $L$. spp. and how is it that they may damage in Daucus carota (Apiaceae), nor about the percentage of pest attack, nor why this is happening in this type of crop. D. carota is a vegetable of great importance worldwide. This manuscript reports the first record of $L$. spp. in leaves of $D$. carota (Apiaceae) in Brazil.
The study was conducted in commercial carrot plantations (cv 'Juliana') in the municipality of Rio Paranaíba and São Gotardo, Minas Gerais, Brazil (19 12' 57.91” S, $46^{\circ} 13$ ' $\left.41.08^{\prime \prime} \mathrm{W}\right)$, with an average temperature of $26.32^{\circ} \mathrm{C}$, $45-98 \% \mathrm{RH}$, and $1,321 \mathrm{~mm}$ annual rainfall and an average altitude of $1,250 \mathrm{~m}$. Sixty carrot plants were selected in three plantations. Sampling was conducted during the drier months (July to September) and raining months (January to March). The evaluated characteristics were the numbers of mined leaflets per plant and mines per plant. The number of mined leaflets and mines per plant were evaluated by performing a direct counting of these features throughout the plant.

During the sampling period, Liriomyza spp. was observed in carrot plantations in Rio Paranaíba and São Gotardo. The higher number of mines per plant, number of mined leaflets, and infested plants (\%) were of 22.10, 12.33 and 21.02, respectively. (Table 1). The mines of $L$. ssp. occur in all leaves. They are meandering and located at the end of the leaves (Figure 1a, b). The leaves when are high infestations become yellow and die within 10 days. This species has been reported causing direct and indirect damage on flowers, and vegetables (Chabi-Olaye et al., 2008). But in the Apiaceae family is the first time we have reported this pest. The occurrence of $L$. spp. on D. carota, contributes to the knowledge of the Liriomyza genus and shows the importance of monitoring and incorporating different control strategies to manage the population of this insect.

Table 1. Plantations, area and attack of leafminer Liriomyza spp. in Daucus carota.

\begin{tabular}{ccccc}
\hline $\begin{array}{c}\text { Plantations } \\
\text { (n=Plants } \\
\text { evaluated) }\end{array}$ & Area (ha) & $\begin{array}{c}\text { Number of } \\
\text { mines/leaf }\end{array}$ & $\begin{array}{c}\text { Number of mined } \\
\text { leaflets/plant }\end{array}$ & $\begin{array}{c}\text { Plants infested } \\
(\% / h a)\end{array}$ \\
\hline $1(n=2,400)$ & 120 & $8.25 \pm 0.12$ & $3.05 \pm 0.02$ & 5.25 \\
$2(n=3,750)$ & 250 & $13.26 \pm 1.05$ & $8.07 \pm 0.11$ & 10.23 \\
$3(n=2,000)$ & 80 & $22.10 \pm 0.29$ & $12.33 \pm 0.03$ & 21.02 \\
\hline
\end{tabular}




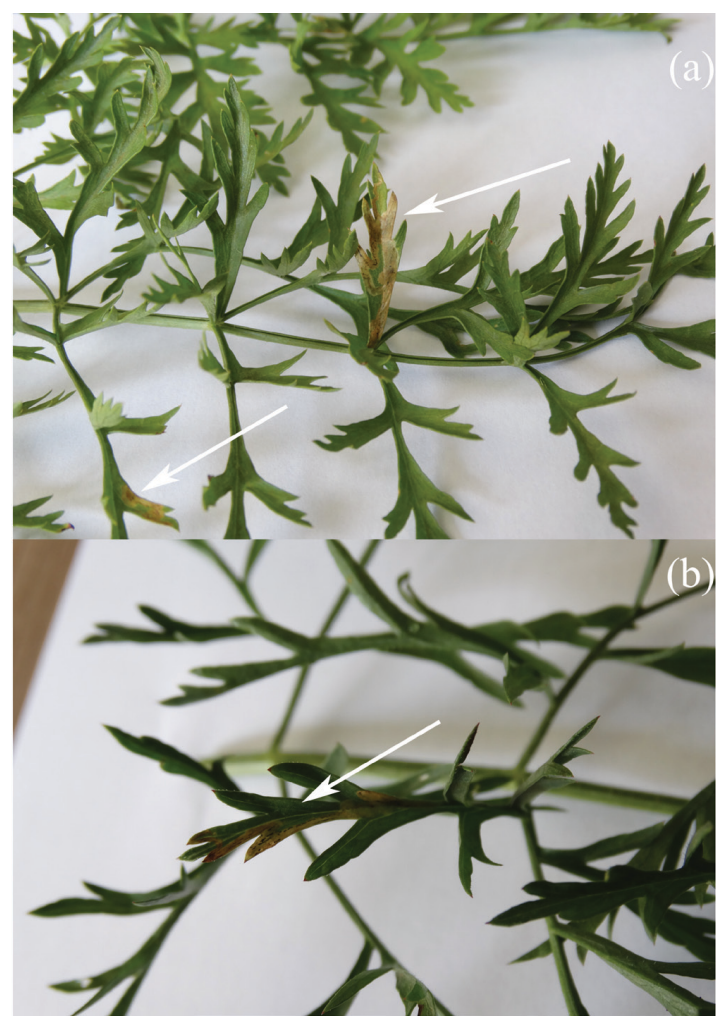

Figure 1. Carrot leaves with one (a), and two mines (b) of Liriomyza spp. Arrows indicate the location of the mine on the sheet.

\section{References}

BUENO, A.F., ZECHMANN, B., HOBACK, W.W., BUENO, R.C.O.F. and FERNANDES, O.A., 2007. Serpentine leafminer (Liriomyza trifolii) on potato (Solanum tuberosum): field observations and plant photosynthetic responses to injury. Ciência Rural, vol. 37, no. 6, pp. 1510-1517. http://dx.doi.org/10.1590/ S0103-84782007000600001.

CHABI-OLAYE, A., MUJICA, N., LOHR, B. and KROSCHEL, J., 2008. Role of agroecosystems in the abundance and diversity of Liriomyza leafmining flies and their natural enemies. In: Proceedings of the Twenty-third International Congress of Entomology, July 2008, Durban City, South Africa. Zagreb: Korunić d.o.o. Zagreb, pp. 6-12.

DURAIRAJ, C., KARTHIKEYAN, G., GANAPATHY, N. and KARUPPUCHAMY, P., 2010. Predisposition effect of Liriomyza trifolii damage to Alternaria leaf spot disease in tomato. Karnataka Journal of Agricultural Sciences, vol. 23, no. 1, pp. 161-162.

FOBA, C.N., SALIFU, D., LAGAT, Z.O., GITONGA, L.M., AKUTSE, K.S. and FIABOE, K.K., 2015. Species composition, distribution, and seasonal abundance of Liriomyza Leafminers (Diptera: Agromyzidae) under different vegetable production systems and agroecological zones in Kenya. Environmental Entomology, vol. 44, no. 2, pp. 223-232. PMid:26313175. http:// dx.doi.org/10.1093/ee/nvu065.

GUANTAI, M.M., OGOL, C.P.K.O., SALIFU, D., KASINA, J.M., AKUTSE, K.S. and FIABOE, K.K.M., 2015. Differential effects of pesticide applications on Liriomyza huidobrensis (Diptera: Agromyzidae) and its parasitoids on pea in Central Kenya. Journal of Economic Entomology, vol. 108, no. 2, pp. 662-671. PMid:26470177. http://dx.doi.org/10.1093/jee/tov006.

JAHNKE, S.M., REDAELLI, L.R., DIEFENBACH, L.M.G. and EFROM, C.F., 2008. Spatial distribution of parasitism on Phyllocnistis citrella Stainton, 1856 (Lepidoptera: Gracillariidae) in citrus orchards. Brazilian Journal of Biology $=$ Revista Brasileira de Biologia, vol. 68, no. 4, pp. 813-817. PMid:19197499. http:// dx.doi.org/10.1590/S1519-69842008000400016.

MARCHIORI, C.H., SILVA, C.G. and LOBO, A.P., 2004. Parasitoids of Tuta absoluta (Meyrick, 1917) (Lepidoptera: Gelechiidae) collected on tomato plants in Lavras, state of Minas Gerais, Brazil. Brazilian Archives of Biology, vol. 64, no. 3a, pp. 551-552. http://dx.doi.org/10.1590/S1519-69842004000300018. PMid:15622852.

QUEIROZ, J.M., 2002. Distribution, survivorship and mortality sources in immature stages of the neotropical leaf miner Pachyschelus coeruleipennis Kerremans (Coleoptera: Buprestidae). Brazilian Journal of Biology $=$ Revista Brasileira de Biologia, vol. 62, no. 1, pp. 69-76. PMid:12185925. http://dx.doi.org/10.1590/S151969842002000100009 .

WEINTRAUB, P.G., 2001. Changes in the dynamics of the leafminer, Liriomyza huidobrensis, in israeli potato fields. International Journal of Pest Management, vol. 47, no. 2, pp. 95-102. http:// dx.doi.org/10.1080/09670870151130516. 